\title{
Business tourism a means of dynamising the life of local communities
}

\author{
Bogdan Gabriel NISTOREANU \\ The Bucharest University of Economic Studies, Bucharest, Romania \\ bogdannistoreanu@yahoo.co.uk \\ Raluca Georgiana STOIAN \\ The Bucharest University of Economic Studies, Bucharest, Romania
}

\begin{abstract}
The touristic expansion happens easier in a balanced climate, with standards that guarantee a constant ecologic balance and avoid the overuse of resources, pollution and any other negative impacts on the environment. MICE - Meeting, Incentive, Convention and Exhibition Industry - represents one of the industries with the highest rate of growth in the world, but unfortunately it is poorly developed in Romania. In Romania, the tourism, as a socio-economic phenomenon, integrates in the country's economy, having the necessary conditions for accentuated growth and the optimisation of the degree of usage of the touristic stock. According to the recommendations of the World Tourism Organisation, Romania should focus on the cultural, ecologic, events and spa tourism. The prognosis of the World Tourism and Travel Council from the United States of America show that by the year 2020, the rhythm of growth of the business and events tourism in Romania will be of about $8 \%$ yearly. In this context, our country may occupy an important position in the MICE touristic activities market, if it would use the existing touristic potential and future investments in order to create favourable conditions for this type of tourism. We bring into the debate the existence of equipment which could help the business tourism, the presence of beautiful landscape areas (the Danube Delta, the Black Sea seaside, medieval cities and monasteries, touristic resorts from the Carpathians also.), presentation of the local folk traditions and crafts, the chromatic spectrum of the seasons in Romania and not lastly the folklore and gastronomy. These could be joined by the existence of a rich cultural life - especially in the large cities and touristic resorts-, the presence of museums and memorial houses, and we could not exclude the areas which have preserved their natural potential and rare fauna species. This work aims to emphasize business tourism as a sustainable form of tourism, which can lead to a relaunch in services and economic development of the local communities in a competitive international economy.
\end{abstract}

Keywords: business tourism, sustainability, economic relaunch, local community.

\section{Introduction to Romanian tourism}

Tourism represents the dynamic branch of the global economy which was developed parallel to the capitalizing of natural tourism resources by modernizing tourist services. In time, this brought major changes in the field of tourism due to the need of satisfying the needs and preferences of customers, which have been changing year to year, due to the fact that customers require high quality tourism services.

In literature belonging to this discipline, the touristic destination is represented by the place or the geographic location where a visitor or a tourist can stop for one or more nights, whether he is traveling for tourism or business. A touristic destination represents the link between the sectors of the tourism industry, such as: accommodation, food, recreation and transportation. This is assessed according to the number of tourists, revenues volume and obtained profit. (Aurelia Stancioiu, 2004)

Currently, business tourism involves creating offers and specialized customised packages in different areas, which differ in terms of quality, resources and benefits offered to the tourists. Classic business did not focus a lot on the development of the 
tourism industry, but with the passing years, tourism has begun to take shape in several categories, and so they began to develop transport services offered to tourists such as: low-cost airlines, additional benefits to customers travelling in business class, etc. Business tourism can be harnessed in the hospitality sector through the provision of quality services both from the professional point of view and also from the behaviour of service providers. In terms of business tourism, one can provide quality services only if the staff is well prepared and trained. (Miron Florea, 2011) It is obvious that business tourism contributes to a better capitalizing of local and national resources, reducing the seasonality, facilitating the emergence of new jobs and increasing the multiplier effect of tourism activities.

\section{A brief analysis of the Romanian tourism activity}

During 2005-2006, in Romania, a decrease by 25\%-26\% in tourist travel could be observed, including business trips and overnights stays, according to information provided by the National Institute of Statistics. (MPDT, 2007).

Tabel 1. The number of tourists, travels and overnight stays internally in 2005 and 2006

(thousands)

\begin{tabular}{|l|l|l|l|l|l|l|}
\hline & $\mathbf{2 0 0 5}$ & $\mathbf{2 0 0 6}$ \\
\hline & Tourists & Travels & Overnights & Tourists & Travels & Overnights \\
\hline Holidays & 6.469 & 8.357 & 38.667 & 5.333 & 6.440 & 29.848 \\
\hline Business & 218 & 379 & 940 & 161 & 248 & 769 \\
\hline Others & 638 & 691 & 7.844 & 442 & 407 & 4.280 \\
\hline TOTAL & 7.325 & 9.427 & 47.451 & 5.936 & 7.095 & 34.897 \\
\hline
\end{tabular}

Source : Romanian National Institute of Statistics.

Classic business tourism in Romania was focused on organizing conferences and exhibitions, and major facilities for these events are found mainly in the Capital city. On the basis of an analysis of the database that National Association of Professional Organizers of Conferences and Exhibitions owns in Romania, it appears that the number of the locations that can organize such events is insufficient. Taking into consideration that Romania is a European Union member, it would be necessary to build as many meeting and conference centres in major cities, with the necessary facilities.

In order to capitalize the business tourism in Romania, it is necessary to make more market studies and raise awareness of these activities in order to organize international conferences. (MPDTN, 2007).

According to MPDTN, road transport infrastructure in Romania has suffered due to the lack of investment over a long period of time, thus leading to the airlines development. According to information from the Romanian Statistic Yearbook, tourist arrivals by air transport have recorded an increase of 260\% during 1990-2004.

Tabel 2. Tourists arrivals (thousands) by means of transport $1990-2004$

\begin{tabular}{|l|l|l|l|l|}
\hline & $\mathbf{1 9 9 0}$ & $\mathbf{1 9 9 5}$ & $\mathbf{2 0 0 0}$ & $\mathbf{2 0 0 4}$ \\
\hline Road & 3.670 & 4.266 & 3.808 & 5.401 \\
\hline Railway & 2.349 & 570 & 660 & 308 \\
\hline By air & 271 & 433 & 655 & 705 \\
\hline Maritime & 242 & 176 & 141 & 186 \\
\hline Total & 6.532 & 5.445 & 5.264 & 6.600 \\
\hline
\end{tabular}


Miron (2011) believes that transport infrastructure is the most important factor in managing the flow of tourists, and the modern highways from abroad constantly attract a large number of tourists.

In order to attract more tourists and to develop this area, it is necessary to: perform upgrading works on the national road network and build highways; improve the railway network and invest in high-speed trains, modernize airports to increase passenger flow.

\section{Advantages of performing MICE activities}

To increase the total number of tourists and the number of overnight stays, an assessment is being carried on of existing tourism markets, and for assessing new destinations, data representing similar destinations is being used. When developing a destination that can bring profit in business tourism, marketers must pay attention to the main characteristics of the respective destination, which is should be developed and improved.

Lately, social and economic transformations of the society have left a mark on the dynamics and efficiency of the tourism sector. According to (Chiriac, 2004), factors such as economic, social and political globalization, influence flexibility in launching offers on the market. Technological innovation, the internet and artificial intelligence represent usage on an increasing scale of these new means of communication, leading an increase in the speed of operating in this sector. We note the following hierarchy of preferences of tourists on trips: on the first place there are business tourism events, followed by the exotic destinations and short vacations / city breaks.

According to Davidson \& Cope, (2003), a trip during which individuals are paid to work, while being far from home and their corporate office, is a clear example of business tourism. Minciu (2007), describes the multitude of events organized by various branches of industry as business tourism, including: international and national symposiums, diplomatic meetings and visits, economic and trade talks, festivals, and cultural, medical, and research congresses, but also large sporting competitions. Even if these activities involve remuneration, they remain a tourism category because they involve the consuming of services in the tourism sector.

Both Davidson \& Cope (2003) and Newstrom \& Scannell (1998) structured the forms of business tourism in terms of content:

- individual business travels / delegations, for many industries, for which the people involved accept to move out of the town of residence;

- tourism meetings that include several types of events such as conferences, seminars, team-building sites, product launches, annual meetings etc.

- fairs and exhibitions for presentation of products and services;

- Travel incentive granted to employees who are performing in their field;

- corporate events organized by companies for major customers or potential customers with whom the companies can initiate and develop business relationships.

Business tourism connects the corporate world with influential organizations in the world of travel. At present, about $40 \%$ of the world travel for many travel agencies is represented by events tourism, with budget accommodation per night increasing by about 20\% per tourist. Nevertheless, Davidson \& Cope (2003) believed that stakeholders considered cultural diversity and work-life balance because a part of conference participants prefer to be accompanied by a partner, and this involves developing additional tourism packages. Thus, profit and growth is guaranteed by 
finding the best deals and related services, such as small tours and excursions. This situation provides an opportunity to promote the event location. A delegate to an event or conference, is worth five leisure travellers, resulting in economic growth.

A business tourist who participates in an MICE event, spends an amount of money much higher than a regular tourist, given that a participant to a MICE event has provided accommodation, travel and subsistence by their companies. Business tourism related activities occur in premises specially designed for such activities so that they involve more specific services or accommodation, food, transport, etc.

\section{MICE in Romania}

MICE in our country is represented by the important investments that operators in the sector have made in the recent years, in conference rooms, equipment, specialized software, outfits and furniture or in raising awareness that the meetings industry is a profitable activity (probably the most profitable touristic activity, as experts say), or in the efforts of crystallising the domain (isolated, discrete, but existing).

Another important thing for MICE was the positive impact that organising major international events in our country had, and also the fact that the tourism authority and some other authorities of the local government, have understood, for a while now, the importance of supporting and carrying out actions to promote Romania as a MICE destination.

Who are the MICE actors? A summary enumeration brings "to the Scene": conference centres, suppliers of technical equipment, interpreters and translators, catering companies, companies that provide floral arrangements, printing services, mass-media, exhibition stands builders, carriers of various types, museums, universities, advertising production companies and many others. So we can say that the MICE industry is a stand-alone field; a "service industry" that brings great benefits to countries, communities and companies who know how to treat it with seriousness and professionalism.

Romania occupies an important place in Europe, taking into account MICE (meetings, incentives, conferences and events) destinations, because it is well-known for its landscapes and existing tourist attractions, such as the Danube Delta and the Black Sea coast, towns and medieval monasteries, and not the least, the tourist resorts of the Carpathians.

An analysis performed by practitioners in the field of tourism activities appreciate that by midyear 2015, "Romania remains in the top 50 countries in the world ranking of the events number hosted (45th) and the Capital has made a spectacular leap, from 98th to 74th" (http://www.jurnalulromanesc.at/romania-se-mentine-in-primele-50-detari-in-clasamentul-mondial-al-numarului-de-evenimente-gazduite/). On the same occasion, Radu Cimponeriu - MICE consultant (Meetings, Incentives, Conventions, Exhibitions) appreciates that 2015 had promising results: „Obviously, this is about MICE events recorded in the ICCA database, according to the criteria of the international organizations, which are quite restrictive, but accepted by everyone. In Romania, from what we have seen so far, 2015 seems to be better than last year ". This considering that 2014 marked a 4\% increase on MICE travel.

\section{Where does MICE "happen" in Romania?}

Bucharest, formerly known as the "Little Paris", famous for its nightlife, has become Romania's economic and touristic centre, due to attractions, museums, galleries and existing architecture monuments. 
Bucharest has 37 museums, 22 theatres, 2 opera halls, 18 art galleries and many bookstores and libraries. Regarding accommodation, Bucharest has almost 400 accommodation units and 11.548 classified accommodation from 5 star hotels to hostels, cottages and network apartments for rent. Regarding hotels, Bucharest has 11 five-star hotels, 77 four-star hotels, 64 three-star hotels, 20 two-star hotels, 5 one-star hotels. As shown, most hotels are dedicated to business people, and thus oriented on the business segment.

In recent years the accommodation for young people has developed and - there are 42 approved hostels in Bucharest. A new form of accommodation is to rent the apartments in hotel-system, as we can find today a number of 483 such equipment classified as $3 *$, totalling more than 1,100 beds.

Important business events can be organized at the Parliament Palace in the conference rooms of the Chamber of Commerce, at the Romexpo venue and at the World Trade Centre. Much of the business events are held at hotels such as InterContinental, JW Marriott Grand Hotel, Hilton Hotel, Pullman (Sofitel), Crown Plaza, Rin Grand Hotel, etc, due to the existing facilities and technical or material capabilities.

According to the National Institute of Statistics, in 2014, Bucharest has received 1.510.222 tourists which recorded 2.497.182 overnight stays. Out of these, 645.718 were Romanian tourists, and 864.504 foreign tourists. The number of tourists increased year to year, thus in 2013 there were 1.328 .190 tourists registered, and in 2012, 1.245.425 tourists. Bucharest received in 2001 only 471.126 tourists; so we find a 3 -fold increase in the number of tourists.

Another destination suitable for MICE Constanta, which has the largest sea port of Romania and is offering many business opportunities both for Romanian investors and for foreign ones. Constanta represents an attraction for both classic tourism and for business tourism from June to September. The business tourism is seasonal in Constanta. Business events can be organized at the Exhibition Centre and in hotels with developed technical and material facilities, such as: Iaki hotel, Hotel Majestic Mamaia Hotel Parc, Savoy, etc. A destination close to Constanta which is suitable for business tourism is UNESCO Danube Delta monument, where, in addition to organizing business events, it offers the opportunity to observe animals and birds in the wild.

In the Central Region of Romania there are both newly built hotels and recently refurbished hotels, offering facilities for business tourism. Tourists visiting for business are able to reach the area by plane or train, given the existence of three airports (ClujNapoca, Sibiu and Targu Mures) and extensive railway network. Many locations that offer facilities for meetings, conferences, etc. are located in the historic centre of the cities or nearby sites. Medieval towns in Transylvania with a unique architecture, that organize most business events are: Cluj-Napoca, Sibiu, Sighisoara, Brasov.

In the eastern part of the country, Moldavia region stands famous for all existing tourist attractions (monasteries with exterior frescoes, authentic food recipes, folklore, etc.). The city which organizes most conferences, meetings and exhibitions is Iasi, the economic and cultural centre of Moldova.

MICE segment is currently seasonal, most business events (meetings, congresses, fairs) being organized in the spring (February - May) and fall (September - November). Subject matter experts state that the segment of team-buildings and conferences starts to recover, taking into account the country's economic environment in recent years. Diminishing the seasonality for the MICE segment can be achieved by organizing business events during summer, whereas in larger cities it is possible to achieve lower costs in low traffic venues. 


\section{Instead of conclusions}

For conferences, meetings and exhibitions (MICE) there are some hotels in which we find both indoors conference rooms and exhibition halls. Event organizers can request from these offers for the business travel segment.

According to the Vacations and Travel magazine, large corporations PICBE|1127 (multinational), high turnover companies with a large numbers of employees, are opting increasingly more for this form of business tourism, considering that the participants are taking part in in debates, training courses, conferences, etc. They opt for full service when organizing an event to be sure that it will be held according to schedule. Organizing a business event starts primarily when establishing the destination, date of deployment and location of the event, followed by the contracting of dedicated service providers for business events (accommodation, transport, restaurant, catering, interpreters, etc.) (Rogojinaru, 2016).

From the perspective of (Swarbrooke and Hower, 2001) business events are named differently from one country to another, so that a small congregation is called a meeting, but a large gathering has different names depending on the country where it is conducted. In the UK we find the name of the conference, in the USA it is called a convention, and congress is preferred in the EU.

Business events generate state budget revenue in the form of taxes, generate profit for all parties' involved, high occupancy and use of existing infrastructure, jobs and advertising. For a business event to be flawless, from organizing to final services offered, it is necessary to involve local governments and authorities which will benefit from these events and activities, generating reflective advantages for the entire community.

Through business tourism locations, regions or cities are being promoted as tourist destinations. Economic efficiency and development of tourism / business events, looked upon especially in terms of economic effects, is in direct relationship with the volume, diversity and quality of offers and additional tourist services. National and international best practices show that one of the important directions of innovation and raising the competitiveness of the tourism offerings of any country is given by the additional services diversification, through stimulating events tourisms dynamics.

\section{References}

Chiriac, A.C, (2004).Asistență turistică în organizarea de evenimente, Editura THR-CG, București.

Dabija, D.C. (2016). Challenges and development prospects for tourism in Romania, Ecoforum, [online] Available at: www.researchgate.net/profile/DanCristian_Dabija/publication/281175841_Challenges_and_development_prospects _for_tourism_in_Romania/links/55d999e208aeb38e8a87d626.pdf, [Accessed 24/01/2016].

Davidson R., Cope B. (2003).Business Travel, Ed. Prentice Hall, Londra.

Minciu, R. (2007). Economia turismului, Editura Uranus, București.

Miron, F. (2011). Georgrafia turismului, Editura Universitatii “Transilvania”, Brasov.

Newstrom J., Scannell E. (1998).The big book of team-bilding games, McGraw Hill, New York.

Rogojinaru, P. (2016). Turismul de afaceri: "afacerea" mileniului III, Revista Vacanțe și călătorii, Ed. Arte, [online] Available at: http://www.vacantesicalatorii.ro/portal/, [Accessed 15/05/2016]; 
Stăncioiu, A.F. (2004). Strategii de marketing în turism, Editura Economică, București.

Swarbrooke, J., Horner, S. (2001). Business travel and tourism, Butterworth-Heinemann, Oxford.

***Autoritatea Națională pentru Turism, [online] Available at: < http://turism.gov.ro>, [Accessed 15/05/2016].

***Asociația Națională a Agențiilor de Turism, [online] Available at: http://www.anat.ro, PICBE | 1128 [Accessed 18/11/2015].

*** International Congress and Convention Association (ICCA), [online] Available at: http://www.iccaworld.com/aeps/aeitem.cfm?aeid=107, [Accessed 18/11/2015].

${ }^{* * *}$ Romanian National Institute of Statistics, [online], Available at: http://www.insse.ro/cms/, [Accessed 18/11/2015].

*** MPDTN (2007) - Master Planul pentru Dezvoltarea Turismului Național în perioada 2007-2026, București.

***Romania Travel, [online] Available at: http://www.romania.travel, [Accessed 16/05/2016].

$* * *$ www.agerpres.ro.

${ }^{* * *}$ www.jurnalulromanesc.at/romania-se-mentine-in-primele-50-de-tari-inclasamentul-mondial-al-numarului-de-evenimente-gazduite/. 